\title{
Profile of cocaine and crack users in Brazil
}

\author{
Perfil dos usuários de cocaína e crack no Brasil
}

\footnotetext{
${ }_{1}$ Departamento de Psiquiatria, Universidade Federal de São Paulo, São Paulo, Brasil.

Correspondence L. B. Duailibi Unidade de Pesquisa em Álcool e Drogas, Departamento de Psiquiatria, Universidade Federal de São Paulo.

Rua Machado Bittercourt 300, apto. 113, São Paulo, SP 04044-000, Brasil.

ligiaduailibi@uol.com.br
}

\begin{abstract}
This article aims to systematize the profile of cocaine and crack users in Brazil. The study adopted a literature review of the MEDLINE, LILACS, Cochrane Library databases and CAPES thesis/dissertation database. Data were grouped in thematic categories: national household surveys, surveys of specific population groups, profile of patients that seek treatment, and mortality and morbidity. Within each category the principal findings from the Brazilian literature were described and then discussed. The article concludes that the information on cocaine and crack consumption in Brazil is still incipient, but that the scientific community can already draw on a relevant theoretical corpus that can be used to update current public policies on this issue.
\end{abstract}

Cocaine; Crack Cocaine; Street Drugs; Drug Abuse
Lígia Bonacim Duailibi 1

Marcelo Ribeiro 1

Ronaldo Laranjeira 1

\section{Introduction}

Cocaine is a central nervous system stimulant extracted from Erythroxylum coca leaves 1. It can be consumed as cocaine hydrochloride, a watersoluble salt, either sniffed or injected. There are also alkaline presentations, volatile at low temperatures, that can be smoked in "pipes", including crack, merla, and cocaine base paste ${ }^{2}$, and non-soluble forms that can be modified to make them "solubilized", and which when injected leads to severe consequences such as increased risk of abscesses, mental disorders, and HIV and hepatitis $\mathrm{C}$ infection.

Coca was consumed for thousands of years by the pre-Inca and pre-Colombian peoples, and cocaine became popular in Europe and the United States beginning in the 19th century, in the form of carbonated tonics and wines 3 . The active ingredient was extracted in the mid-19th century, and at the turn of the $20^{\text {th }}$ century a large contingent of users consumed the substance for medical and recreational purposes 4 . The appearance of cases with acute and chronic complications led to the ban on the substance in the main Western countries beginning in the 1910s and 20s 5,6.

However, in the late 1970s and early 80s, the substance regained popularity in Western societies as a glamour drug, attuned with the big-city workaholic environment. This setting, in which cocaine had become the main attraction, contrasted with the emergence of crack less than ten 
years later. Since then these drugs have coexisted in various proportions in different cities and contexts 7 . This new situation, unlike the previous one, spread particularly in socially excluded locations, with boys living on the streets and injecting drug users (IDUs) as the main target ${ }^{8}$. Outreach services 9,10 and the media 11 quickly detected this change. In the mid 1990s, cocaine and crack users became the group of illicit drug users that most turned to outpatient and inpatient services for addiction treatment 9 .

This phenomenon spawned various published studies on cocaine and crack. However, little is known about the profile of cocaine and crack users. In order to the collect the available knowledge on this subject in Brazil, we conducted a literature review on the principal socio-demographic profiles of cocaine and crack users, targeting household surveys, specific population groups, and the main health services. We also outline the pattern of morbidity, mortality, and cause of death among users.

\section{Materials and methods}

The socio-demographic profiles of Brazilian cocaine and crack users were presented according to two criteria defined by the authors: (1) an overall socio-demographic of cocaine and crack users, followed by an investigation of specific populations and treatment settings, as well as complications from use and, (2) within each topic, a presentation of the articles according to their degree of methodological complexity.

Brazilian articles, theses/dissertations, and book chapters on cocaine consumption were identified, including work published from the mid-1980s forward. The following databases were consulted: MEDLINE [http://www.pubmed. com]; LILACS (Latin-American and Caribbean Literature in Health Sciences); and the PanAmerican Health Organization collection, consulted through the BVS (Virtual Health Library) [http://www.bireme.br], the Brazilian Center for Information on Psychoactive Drugs (CEBRID) [http://www.cebrid.epm.br]; and the thesis/dissertation database of CAPES (Coordinating Division for Graduate Studies) [http://www.capes. gov.br]. With the theses/dissertations, the authors analyzed the full texts of studies conducted in the State of São Paulo, Brazil. When the theses or dissertations produced complete articles (indexed in the databases consulted) we prioritized the articles. For other States of Brazil, we consulted the abstracts published in the CAPES website. In case of any doubt about the profiles in the samples, the authors were contacted through their e-mails, identified in their resumés in the Lattes database.

In all the databases, the descriptors "cocaine" and "crack" were combined with descriptors related to the current article's theme: "history", "profile”, “epidemiology”, “women”, “adolescents", "street children”, "treatment”, "violence”, and "mortality". The search was conducted in Portuguese and English.

\section{Results}

\section{National household surveys}

All the national epidemiological surveys were conducted by CEBRID. The first studies were published in the late 1990s. In 1999, CEBRID held a household survey covering the 24 largest cities in the State of São Paulo ${ }^{12}$. Rate of any lifetime cocaine use was $2.1 \%$, and was higher in the $26-34$-year age bracket $(4 \%)$. Lifetime crack use was $0.4 \%$. Two years later, the 1 st National Household Survey on Use of Psychoactive Drugs in Brazil (2001) 13 interviewed individuals in 107 cities with more than 200,000 inhabitants each. Lifetime cocaine use was $2.3 \%$ overall, and was higher in the South (3.6\%) and Southeast (2.6\%) of the country, intermediate in the Northeast (1.4\%) and Central West (1.4\%), and lower in the North $(0.8 \%)$. Again, the highest prevalence was in the 25-34-year age bracket (4.4\%), especially among males (7.2\%). Lifetime crack use was $0.7 \%$ for males, and lifetime use of merla appeared in the North, with $1 \%$, the highest rate in Brazil. The highest rates for both substances were among young males, with $1.2 \%$ (crack) and $0.5 \%$ (merla) for 25-34-year-old men.

\section{Specific populations}

\section{- Primary and secondary students}

Different institutions have conducted studies focusing on specific and regional realities. However, the most relevant epidemiological studies in this population group were by CEBRID, with a total of five surveys (1987, 1989, 1993, 1997, and 2004) $14,15,16,17,18$. The first four interviewed a random sample of students in ten State capitals $14,15,16,17$ and the fifth included 27 State capitals of Brazil 18. In the latter, lifetime cocaine use by students was $2 \%$, reaching $2.9 \%$ in the North, $2.3 \%$ in the Southeast, $2.1 \%$ in the Central West, $1.7 \%$ in the South, and $1.2 \%$ in the Northeast. As compared to the four previous studies, there was a significant increase in cocaine consumption among students in the State capitals of the 
Northeast (Salvador, Bahia; Recife, Pernambuco; and Fortaleza, Ceará). In the Southeast, only São Paulo maintained a similar rate to the four previous surveys, while there was an increase in consumption in Belo Horizonte (Minas Gerais) and Rio de Janeiro. There was no change in the cocaine consumption rate among students in Curitiba (Paraná) and Porto Alegre (Rio Grande do Sul).

Another national survey interviewed a probabilistic sample of 50,740 students from 673 public and private primary and secondary schools in 14 State capitals: Belém (Pará), Brasília (Federal District), Cuiabá (Mato Grosso), Florianópolis (Santa Catarina), Fortaleza, Goiânia (Goiás), Maceió (Alagoas), Manaus (Amazonas), Porto Alegre, Recife, Rio de Janeiro, Salvador, São Paulo, and Vitória (Espírito Santo) 19. Lifetime cocaine use was $1 \%$, lifetime crack and merla rates were $0.5 \%$ each, and injecting drug use $0.3 \%$. According to the study, consumption was more prevalent among boys and increased with age in both sexes. In addition to the national surveys, some studies have attempted to measure drug consumption in some Brazilian municipalities, showing lifetime rates from $1 \%$ to $3.5 \%$ (Table 1 ).

\section{- University students}

The majority of the scientific articles on university students focused on medical students (Table 2). Most cocaine users in the target universities were 20-24-year-old single males, living with friends or alone, non-religious, and with difficult relations with their parents, especially with their mothers. Risk factors associated with cocaine use

Table 1

Rates of any lifetime cocaine use, use in previous 12 months, and use in previous 30 days among primary and secondary students, Brazil.

\begin{tabular}{|c|c|c|c|c|c|c|}
\hline \multirow[t]{2}{*}{ Reference } & \multirow[t]{2}{*}{ Year of study } & \multirow[t]{2}{*}{ City/State } & \multirow[t]{2}{*}{ Sample } & \multicolumn{3}{|c|}{ Cocaine use (\%) } \\
\hline & & & & Lifetime & Last 12 months & Last 30 days \\
\hline Boskovitz 88 & 1992 & $\begin{array}{l}\text { São José do } \\
\text { Rio Preto/SP }\end{array}$ & $\begin{array}{l}\text { Random sample from clusters } \\
\text { of primary and secondary students } \\
\text { in the municipal school system }\end{array}$ & 2.4 & - & - \\
\hline Muza et al. 89 & 1997 & Ribeirão Preto/SP & $\begin{array}{c}11,250 \text { public and private elementary } \\
\text { and secondary students }\end{array}$ & 2.7 & - & - \\
\hline Guimarães et al. 90 & 2004 & Assis/SP & $\begin{array}{l}\text { Random selection of } 20 \% \text { of students } \\
\text { from } 18 \text { public and private schools }\end{array}$ & $1.7 / 1.2$ * & - & - \\
\hline Vieira 91 & 2003 & Paulínia/SP & $\begin{array}{l}\text { Random sample of elementary and } \\
\text { secondary public and private students }\end{array}$ & - & 2.1 & - \\
\hline Soldera et al. 92 & 1998 & Campinas/SP & $\begin{array}{l}\text { Random sample of public } \\
\text { and private students }\end{array}$ & - & - & 1.4 \\
\hline Godoi et al. 93 & 1988 & Brasília/DF & Random sample of private students & 1.8 & - & - \\
\hline Souza \& Martins 94 ** & 1995 & Cuiabá/MT & Random sample of public students & 1.8 & - & - \\
\hline Almeida $85 * \star$ & 1997 & Cuiabá/MT & Random sample of public students & 1.1 & - & - \\
\hline Baus et al. 95 & 1997 & Florianópolis/SC & $\begin{array}{l}478 \text { students from a public } \\
\text { elementary and secondary school }\end{array}$ & 3.3 & - & - \\
\hline Tavares et al. 96 & 1998 & Santa Maria/RS & $\begin{array}{l}\text { Random sample of } 1,074 \text { public } \\
\text { and private students }\end{array}$ & 1.7 & - & - \\
\hline Deitos et al. 97 & 1998 & Pelotas/RS & $\begin{array}{c}\text { Random sample of } 2,410 \text { public and } \\
\text { private students } 10-19 \text { years old }\end{array}$ & 3.2 & - & - \\
\hline
\end{tabular}

DF: Distrito Federal; MT: Mato Grosso; RS: Rio Grande do Sul; SC: Santa Catarina; SP: São Paulo.

* Rates of cocaine use among public and private students, respectively;

** Both epidemiological surveys were conducted by the same group of researchers, Health and Environmental Department, Federal University in Mato Grosso. 
Table 2

Rates of any lifetime cocaine use, use in previous 12 months, and use in previous 30 days among university students, Brazil.

\begin{tabular}{|c|c|c|c|c|c|c|}
\hline \multirow[t]{2}{*}{ Reference } & \multirow[t]{2}{*}{ Year of study } & \multirow[t]{2}{*}{ City/State } & \multirow[t]{2}{*}{ Sample } & \multicolumn{3}{|c|}{ Cocaine use (\%) } \\
\hline & & & & Lifetime & Last 12 months & Last 30 days \\
\hline Magalhães et al. 20 & 1990 & São Paulo/SP & $\begin{array}{l}1,069 \text { university students from } \\
20 \text { schools in the capital }\end{array}$ & 10.0 & - & - \\
\hline Andrade et al. 98 & 1993 & São Paulo/SP & $\begin{array}{l}\text { Serial study with } 1 \text { st to } 6 \text { th year } \\
\text { medical students at the University } \\
\text { of São Paulo (1991, } N=796 \text {; } \\
\text { 1992, } N=747 ; 1993, N=761 \text { ) }\end{array}$ & - & 2.8 & 2.0 \\
\hline Andrade et al. 99 & 1994 & $\begin{array}{l}\text { São Paulo } \\
\text { (capital and interior)/SP }\end{array}$ & $\begin{array}{l}\text { 1st to 6th year medical students } \\
(N=5,225) \text { from nine schools } \\
\text { in the capital and interior, } \\
\text { State of São Paulo }\end{array}$ & $3.0-7.0$ & - & $0.2-4.0$ \\
\hline Queiroz 21 & 1996 & São Paulo/SP & $\begin{array}{l}\text { Students, University of } \\
\text { São Paulo }(N=2,564)\end{array}$ & 7.1 & - & - \\
\hline Barria et al. 22 & 1996 & São Paulo/SP & $\begin{array}{l}\text { Students, University of } \\
\text { São Paulo }(N=2,564)\end{array}$ & 7.1 & - & - \\
\hline Fabris 100 & 2001 & $\begin{array}{c}\text { Presidente } \\
\text { Prudente/SP }\end{array}$ & $\begin{array}{l}\text { 1,127 university students } \\
\text { from the human, exact, } \\
\text { and biological sciences, } \\
\text { West São Paulo University }\end{array}$ & - & $4.2 / 2.3 *$ & - \\
\hline Ribeiro et al. 101 & 1996 & Juiz de Fora/MG & $\begin{array}{l}390 \text { 1st to 6th year medical } \\
\text { students at the Federal } \\
\text { University in Juiz de Fora }\end{array}$ & 5.6 & - & - \\
\hline Pereyra et al. 102 & 1996 & Belo Horizonte/MG & $\begin{array}{l}331 \text { medical students at the } \\
\text { Federal University in Minas Gerais }\end{array}$ & 1.0 & - & - \\
\hline Plotnik et al. 23 & 1985 & Porto Alegre/RS & 743 university students & - & 12.0 & - \\
\hline Brenes et al. 24 & 1985 & Pelotas/RS & Random sample of university students & - & - & 5.0 \\
\hline Albino et al. 25 & 2002 & Palhoça/SC & $\begin{array}{c}\text { 1,604 students at the Pedra Branca } \\
\text { campus of the South Santa } \\
\text { Catarina University }\end{array}$ & 1.0 & - & - \\
\hline Souza et al. 103 & 1997 & Fortaleza/CE & $\begin{array}{l}627 \text { medical students at the } \\
\text { Federal University in Ceará }\end{array}$ & 1.8 & 0.6 & 0.5 \\
\hline Torres 104 & 2002 & Fortaleza/CE & $\begin{array}{c}325 \text { students at the schools of } \\
\text { pharmacy, dentistry, and nursing, } \\
\text { Federal University in Ceará }\end{array}$ & - & - & 1.0 \\
\hline Coelho 105 & 2002 & Fortaleza/CE & $\begin{array}{l}354 \text { medical students, } \\
\text { State University of Ceará }\end{array}$ & 4.3 & - & - \\
\hline Canuto 106 & 2003 & Goiânia/GO & $\begin{array}{l}\text { 1,080 first year students from } 20 \\
\text { courses (selected from a total of } 39 \text { ) } \\
\text { at the Federal University in Goiás }\end{array}$ & 2.6 & - & - \\
\hline
\end{tabular}

CE: Ceará; MG: Minas Gerais; RS: Rio Grande do Sul; SC: Santa Catarina; SP: São Paulo.

* Rate of cocaine use in the previous year for men and women, respectively. 
in this group were: having drug-using parents or friends, having used drugs before entering the university, working, low grade point average, the course and places frequented in the university, and approving regular marijuana use by anyone connected to the individual $20,21,22,23,24,25$.

\section{- Children and adolescents on the streets}

The fifth national CEBRID survey 26 investigated drug use among children and adolescents (10-18 years of age) on the streets in 27 Brazilian State capitals. The highest intranasal cocaine rates in the previous month were in Rio de Janeiro (45.2\%), São Paulo (31\%), Boa Vista, Roraima (26.5\%), Brasilia (23.9\%), and Recife (20.3\%). Only eight interviewees $(\mathrm{N}=2,807)$ reported recent cocaine injecting, with the highest number in Salvador $(n=3)$. Frequent crack use was mentioned in most of the State capitals. The highest rates of recent use were in São Paulo, Recife, Curitiba, and Vitória, ranging from $15 \%$ to $26 \%$. In São Paulo, the predominant form of consumption was mesclado or "mixed" (crack and marijuana mixed as cigarettes). Any lifetime use of merla was mentioned in 18 State capitals. Recent merla use was reported in Brasilia (19.3\%), Goiânia (17.1\%), São Luís (15.5\%), and Boa Vista (10.3\%).

Children and adolescents on the streets in Brazil began using crack in the late 1980s, especially in the South and Southeast. There was a steady increase in consumption, as shown by the consecutive surveys (1987, 1989, 1993, 1997, and 2004) 14,15,16,17,18 and corroborated by other studies 27,28. There was an increase in São Paulo from 1989 to 1993, in Porto Alegre from 1993 to 1997, and in Rio de Janeiro from 1997 to 2003, although the rate was already high in 1993. In the Northeast, cocaine and crack consumption was insignificant until 1997 (around 1\%), but there was a significant increase in 2003, reaching $10.3 \%$ in Fortaleza, and $20.3 \%$ in Recife, suggesting an increase in the availability of coca products in the region.

\section{- Sexual risk behavior}

Cocaine and crack consumption have been associated directly with HIV infection 29,30 . The most frequently observed risk behaviors are the high number of partners, unprotected sex, and trading sex for crack or for money to purchase the substance 30,31 . In a study of 388 adolescents, mostly females (13-20 years), who came spontaneously to public HIV testing services in Porto Alegre, self-reported unprotected sexual relations and trading sex for drugs were directly associated with positive HIV serology 32 . Another study in Porto Alegre followed 138 cocaine users for 18 month to investigate the incidence of HIV infection during this period. The authors identified sexual transmission as the main transmission route among these users ${ }^{33}$. In Cuiabá, Mato Grosso, a study comparing HIV+ patients and healthy blood donors showed that a high number of sex partners, low schooling, and cocaine use in the previous six months were independent risk factors for HIV infection ${ }^{34}$.

A study in Rio de Janeiro interviewed 675 men from 18 to 50 years of age with negative HIV serology and a history of sex with men in the previous six months 35 . The study showed that vulnerability to HIV infection was associated with poverty, low schooling, and drug use (especially cocaine and crack). Another study with predominantly male crack users in Campinas (São Paulo) detected HIV in $11 \%$ of users, relating crack use and unprotected sex to the risk of HIV infection 36 .

A behavioral study in women who traded sex for crack by Nappo et al. 30 in the city of São Paulo and in São José do Rio Preto (São Paulo State) in 2004, using a qualitative design with a sample of 75 individuals selected with the "snowball" technique showed that the interviewees were predominantly young mothers with low schooling, lived with the family (parents or steady partners), and were home providers themselves. The majority had sex for crack daily (ranging from 1 to 5 casual partners), did not choose either these partners or the type of sex they practiced, and did not value condom use. Another study with prostitutes in the area known as Cracolândia or "Crackland" in downtown São Paulo showed similar risk behavior 37 . Likewise, in the port area of Santos (São Paulo), 1,047 prostitutes interviewed from 1995 and 1998 showed a positive association between crack consumption and injecting drugs and increased HIV seroprevalence 38 .

Although trading sex for drugs was more frequent in women, it also occurred in men, regardless of sexual orientation 39 . No specific national studies on this theme were identified, but a study of 13 hustlers, 53 transvestites, and 449 prostitutes in Ribeirão Preto (São Paulo) showed that crack and injecting cocaine greatly increased the risk of HIV infection. All three groups evidenced cases of prostitution for the sole purpose of procuring drugs 40 .

\section{- Injecting drug users}

HIV transmission through injecting drug use mainly affects poor individuals with low schooling. One study in São Paulo reviewed all cases of AIDS in females 10 years of age or older in the State of São Paulo from 1983 to 1992 and 
observed that contamination through injecting drug use was more common among women with low schooling, while sexual transmission predominated among women with higher education and professional occupations 41 .

In a study of 839 cocaine users at seven treatment centers in São Paulo, from 1997 to 1998, those with a history of injecting drug use showed nearly 26 times the odds of having three or more infections, as compared to non-users 42 . Three studies in São Paulo 43,44,45 and one in Porto Alegre 46 also showed an association between injecting cocaine and HIV infection.

Another Brazilian study used the "snowball" technique to select 668 IDUs in seven Brazilian cities: Santos, Salvador, Rio de Janeiro, Itajaí (Santa Catarina), Corumbá (Mato Grosso do Sul), Cuiabá, and Goiânia ${ }^{47}$. The sample was selected from 1993 to 1996. Cocaine was the injecting drug of preference among these users (92\%). They had injected drugs for an average of ten years, and $57 \%$ had injected in the previous two months. They injected on average seven times a day, and the vast majority reported reusing injecting equipment (83\%) and sharing syringes (71\%). Trading sex for drugs was reported by $38 \%$ of users. HIV infection rates varied from $30 \%$ (Rio de Janeiro and States in the Central West) to $70 \%$ (Santos and Itajaí).

Aiming to monitor trends in HIV infection rates and consumption patterns among IDUs, Mesquita et al. ${ }^{48}$ conducted a comparative study between groups, with a sample of users in Santos, interviewed in 1991-1992 ( $\mathrm{N}=214), 1994-1996$ ( $\mathrm{N}=135)$, and $1999(\mathrm{~N}=108)$. The authors noted a decrease in frequent use ( $\geq 5$ times a day) of injecting cocaine $(42 \%, 30 \%$, and $15 \%$; $p<0.001)$, along with an increase in crack consumption $(11 \%, 60 \%$, and $67 \% ; \mathrm{p}<0.001)$. The transition in administration routes may have contributed to the drop in HIV infection rates during the pe$\operatorname{riod}(63 \%, 65 \%$, and $42 \% ; \mathrm{p}<0.001)$. IDUs are also exposed to other diseases besides AIDS, particularly tuberculosis 49,50 and hepatitis C 51,52.

\section{- Crack users}

The first research on crack consumption in Brazil was an ethnographic study in the city of São Paulo, with 25 users living in the community 8 . The authors report that the substance first appeared and spread in 1989. Typical users were poor men, under 30 years, unemployed, with limited schooling, from broken homes.

According to the same study, crack users (as compared to powder cocaine) involved a more serious consumption pattern, more involvement in illicit activities, more propensity to adverse effects from use, more involvement in prostitution, and higher odds of living (or having lived) on the streets. Users also had more social and health problems than intranasal cocaine users 44 . In recent years, crack users have also began to appear among higher-income groups, although the drug is still more prevalent among lower-income classes 53 .

Crack users are usually multiple drug users or have a history of consuming other substances. $8,44,45$. Evaluating the history of patients younger than 30 years, most debuted with psychoactive substances starting with legal drugs (tobacco and alcohol), at an early age, and with heavy use 44,54. Marijuana was usually the first illicit drug 55 . Among older users, sniffing cocaine and medicines and injecting cocaine also preceded their crack use. Users that consumed both crack and intranasal cocaine tended to begin earlier than those that only used one of the two forms 54 . The first experience with the substance was generally sniffing, moving to crack later 54 .

\section{Profile of patients that seek treatment}

The consumption pattern of cocaine and crack users currently in treatment appeared to be heavier than for users who were off treatment 44 . Crack users appeared to seek treatment earlier than intranasal cocaine users 44,56. Patients using crack frequently also used other drugs, especially alcohol, tobacco, and marijuana 44,45,56.

\section{- Outpatient treatment}

Specialized outpatient services detected an increase in consumption beginning in the early 1990s. By the mid-1990s, cocaine and crack users, who had initially comprised less than a fifth of outpatient demand related to illicit drugs, now occupied $50-80 \%$ of the demand in these health services $57,58,59,60,61,62,63$.

Two cross-sectional studies on cocaine and crack addicts followed in various treatment settings (outpatient services, clinics, and shelters) in São Paulo 44,56 found a similar socio-demographic profile to that described for crack users in the community ${ }^{8,56}$. Studies in São Paulo and Rio de Janeiro on crack users from a single service $8,44,56,57,58,59,60,61,62,63,64$ found similar results as to the profiles of cocaine and crack users.

\section{- Hospitalization}

As with outpatient services, cocaine-related hospital admissions also began to increase in the 1990s. According to studies by CEBRID 12,13, in the early 1990 s there was a $77 \%$ increase in the 
number of patients admitted for cocaine-related treatment, accounting for $14 \%$ of hospitalizations for drug use (alcohol not included) in 1989, reaching $25 \%$ by 199210 .

Crack addiction was the most frequent cause of cocaine-related hospitalization. In a crosssectional study of 440 patients in six psychiatric hospitals in Greater São Paulo in 1997-1998, 70\% of patients admitted for cocaine problems were crack users 65 . Crack was also the most widely consumed substance among 406 patients hospitalized for illicit drug addiction in the city of Marília (São Paulo State), with frequencies ranging from $62.9 \%$ for men to $87.5 \%$ for women 66 . Likewise, a retrospective study in Curitiba investigated medical charts of adolescents (10-20 years) hospitalized for drug addiction $(\mathrm{N}=682) 67$, among whom crack was the second most frequently used substance (49\%), with decreasing proportions of consumption of substances like alcohol (39\%) and intranasal cocaine (29\%). On the other hand, according to a study of cocaine addicts hospitalized in Porto Alegre, only onethird were crack users 68 .

Hospitalized crack users showed worse social indicators compared to intranasal cocaine users 44 . Crack addicts were also more like to have used other administration routes, including injecting, thus exposing them to increased risk of HIV infection and hepatitis C 44,69,70.

\section{- Comorbidities}

The presence of a second psychiatric diagnosis is common among cocaine and crack users 71 . Depression and anxiety disorders are the most frequently observed psychiatric comorbidities in Brazilian studies on these users 72,73.

The presence of comorbidities increases the severity of both diseases: a study of 50 inpatients in Porto Alegre found a significant correlation between depressive and anxious symptoms and severity of addiction 74 . Likewise, a case-control study of 208 cocaine users in Rio de Janeiro showed that the presence of comorbidities increased the risk of harmful cocaine use, with alcohol addiction as the disorder most frequently associated with future development of cocaine abuse/addiction 75. Finally, a follow-up study in Rio de Janeiro with 119 users of cocaine base paste showed that although the patients presented a high depression rate, part of the depressive symptoms disappeared after the withdrawal symptoms resolved, highlighting the importance of a withdrawal period for obtaining a more accurate diagnosis 76 .

\section{- Acute complications}

Cocaine users, independently of the administration route, are prone to adverse reactions and complications related to consumption: in a study of 332 cocaine users in different health units (outpatient services, clinics, and shelters) in the city of São Paulo 77, half reported some type of adverse reaction resulting from consumption, such as heat and flushes (84\%), uncontrollable tremors (76\%), and malaise (75\%). Seizures (18\%) and fainting (21\%) were the acute complications most frequently reported by participants. These complications were more common in regular users, especially among those off treatment, with a history of injecting cocaine, with a diagnosis of severe addiction, and in simultaneous use of benzodiazepines. Overdose was also a recurrent complication: in a study of 396 cocaine users from the city of Santos $78 ; 20 \%$ reported one or more episodes of overdose, and $50 \%$ knew someone who had suffered an overdose.

\section{- Predictive factors for treatment dropout and adherence}

Among all addicts of psychoactive drugs, cocaine and crack users have the highest treatment dropout rates. Evidence suggests the following predictive factors for dropout: problems with the law, low social coping skills, loss of parents in childhood, family history of mental disorder, and associated alcohol addiction disorder 67,68,69,70,71. Crack users appear to be more prone to abandoning treatment than users of intranasal cocaine 44,56 .

As for adherence factors, there is a positive relationship between multiplicity of treatment proposals (pharmacological treatment, referral to mutual help groups, care for mothers, care for families, and general medical care) and better treatment adherence 79,80 . This reinforces the idea that cocaine and crack users need more intensive and prolonged approaches than other addicts. Specialized treatment services for women appear to be more effective for treatment of alcohol abuse than for cocaine and crack use, possibly due to the latter group's heterogeneity 81 . The presence of psychiatric comorbidities 80,82 is associated with a worse prognosis among drug users. Producing evidence in the opposite direction, a study of cocaine and crack users hospitalized for treatment in the city of Pelotas (Rio Grande do Sul) from 1998 to 2000 concluded that the presence of an association between major depression and cocaine addiction increased adherence by such patients to the treatment plan 83 . 


\section{Mortality}

Cocaine and crack users appear to be especially vulnerable to deaths from external causes. In a five-year follow-up study of 131 crack users hospitalized in a detoxification ward in São Paulo, 23 (18\%) died over the course of the study 45,84 . The annual mortality rate among crack users admitted to the Taipas General Hospital (1992-1994) was high $(2.5 \%)$, seven times higher than the overall mortality rate in the city of São Paulo during the same period. The majority of the patients who died were men under 30, single, with low schooling. External causes accounted for $69.6 \%$ of the deaths $(n=16)$, of which 13 were homicides (56.6\%), two overdoses (8.7\%), and one drowning (4.3\%). Natural causes accounted for $30.4 \%$ of the deaths $(n=7)$, of which six were due to HIV/AIDS (26.1\%) and one to hepatitis B (4.3\%). Previous drug injecting, unemployment, and a history of previous treatment were considered risk factors for death in the study sample.

\section{Discussion}

Although numerically few and with limited samples, the publications on cocaine consumption in Brazil portray relevant aspects, besides identifying gaps requiring further specific studies.

In general, cocaine products are consumed by a small share of the Brazilian population (2.3\%), with the highest rates in the South and Southeast. Cocaine use is more common among male adolescents and young adults. The presentations for smoking display important regional variations, with crack more common in the South and Southeast and merla in the North 12,13.

Given that the first episode of consumption typically occurs during adolescence, epidemiological surveys with students are important yardsticks for the consumption of psychoactive substances. This phenomenon appears to be more likely in settings marked by grade-for-age lag in school, truancy, low socioeconomic status, poor relations with parents and or permissive parents, abuse, and lack of religion 18,19,85.

Among university students, the limited number of studies and the relatively small samples of students prevent any conclusion on the precise profile of users in this group (broader surveys are still needed). Among the main studies $20,21,22,23,24,25$, peer influence and family permissiveness, together with the more independent university lifestyle, are important risk factors for cocaine use, suggesting that these fields should be approached for prevention and treatment among this group.
We observed a considerable and progressive increase in cocaine/crack consumption in children and adolescents living on the streets, especially in the States of the South and Southeast, as shown by national surveys from 1987 to 2004 14,18 . These studies also evidenced the increased availability of cocaine in the Northeast, especially in the cities of Fortaleza and Recife, and since 2003 the regional differences are no longer as great between the Southeast and Northeast of Brazil in relation to this drug's consumption and availability. Importantly, the crack consumption pattern in São Paulo has changed to the mesclado form 26.

Even though it affects a small portion of the population, a relevant aspect of cocaine and crack consumption in Brazil is HIV infection and other STDs 35,36, considering that a large share of the Brazilian studies highlighted that cocaine/ crack use accounted for an increase in the risk of acquiring these infections, both through the high number of sex partners and unprotected sex 31 and trading sex for crack itself or for money to purchase it $30,31,32$. Although there are signs that cocaine injecting has decreased in recent years 48 , it still appears to affect poor groups with limited schooling, the idiosyncrasies of which require specific approaches capable of reducing harm and guaranteeing access to health for these individuals 47,48 .

Among the illicit drugs, crack is perhaps the substance whose treatment demand has increased the most in recent years 65 . The profile of crack users (young, unemployed, unschooled, poor, from broken families 53 , and with a history of injecting drugs 84 and risky sexual behavior 47,48 ) makes it difficult for these individuals to adhere to treatment, thus requiring more intensive and appropriate approaches for each treatment phase 86 . Other difficulties experienced by cocaine/crack users in seeking and adhering to treatment are the lack of recognition of their use as a problem, the illegal status and crime related to these drugs, the stigma and prejudices, and lack of access to services or refusal to accepts exiting services 87 . Factors that favor better adherence include: pharmacological therapy, referral to mutual help groups, care for mothers and other family members, and general medical care 79,80 .

Psychiatric comorbiditiesarecommonamong cocaine/crack users and aggravate the prognosis for both diseases 75,80,82. A differential diagnosis as to the presence or absence of comorbidities is mandatory 76 . Acute complications related to the use of these drugs - independently of the administration route - are more common among regular users, especially those who are off treat- 
ment, with a history of cocaine injecting, with a diagnosis of severe addiction, and in simultaneous use of benzodiazepines 77 . Finally, mortality was closely related to external causes, especially violent deaths 45,84 .

Information on cocaine and crack consumption in Brazil is still insufficient, especially when attempting to conceive public health measures informed by scientific evidence and capable of dealing with all the specificities related to pre- vention and treatment of such substance abuse. However, the last 20 years have witnessed increasing production of consistent scientific knowledge on this theme, encompassing various aspects linked to the consumption of these drugs. New epidemiological studies and surveys are needed in all the fields discussed here, considering that the information presented in the current article already provides a basic overview of this population.

\section{Resumo}

Este artigo tem como objetivo sintetizar o perfil dos usuários de cocaína e crack no Brasil. Foi construído por meio de revisão da literatura com base em dados (MEDLINE, LILACS e Biblioteca Cochrane) e no banco de teses da CAPES. Os dados foram agrupados em categorias temáticas, quais sejam: levantamentos domiciliares nacionais, populações específicas, perfil dos pacientes que procuram tratamento, mortalidade e morbidade. Dentro de cada categoria os principais achados da literatura nacional foram descritos e posteriormente discutidos. O artigo conclui que informações relacionadas ao consumo de cocaína e crack no Brasil ainda são incipientes, mas já temos à disposição da comunidade científica um conjunto teórico relevante que pode ser utilizado visando à atualização das atuais políticas públicas referentes a este tema.

Cocaína; Cocaína Crack; Drogas Ilícitas; Abuso de Drogas

\section{Contributors}

L. B. Duailibi participated in the design, drafting, and final editing of the article. M. Ribeiro contributed to the design and initial draft of the article and its revision. $\mathrm{R}$. Laranjeira collaborated in the design, thematic topics, and final revision of the content and article. 


\section{References}

1. Ribeiro-Araújo M, Laranjeira R, Dunn J. Cocaína: bases biológicas da administração, abstinência e tratamento. J Bras Psiquiatr 1998; 47:497-511.

2. Benowitz NL. How toxic is cocaine? In: CIBA Foundation, editor. Cocaine: scientific and social dimensions. Chichester: John Wiley and Sons; 1992. p. 125-42.

3. Karch SB. Celebrity drug endorsements. In: Karch $\mathrm{SB}$, editor. A brief history of cocaine. Boca Raton: CRC Press; 1998. p. 23-36.

4. Ferreira PEM, Martini RK. Cocaína: lendas, história e abuso. Rev Bras Psiquiatr 2001; 23:96-9.

5. Carneiro BHS. A vertigem dos venenos elegantes [Doctoral Dissertation]. São Paulo: Pontifícia Universidade Católica de São Paulo; 1993.

6. Carlini EA, Notto AR, Galduróz JC, Nappo AS. Visão histórica sobre o uso de drogas: passado e presente; Rio de Janeiro e São Paulo. J Bras Psiquiatr 1996; 45:227-36.

7. Bieleman B, Diaz A, Merlo G, Kaplan CD. Lines across Europe: nature and extent of cocaine use in Barcelona, Rotterdam and Turin. Amsterdam: Swets \& Zeitlinger; 1993

8. Nappo SA, Galduróz JC, Noto AR. Uso do "crack" em São Paulo: fenômeno emergente? Rev ABPAPAL 1994; 16:75-83.

9. Dunn J, Laranjeira R, Silveira DX, Formigoni MLOS, Ferri CP. Crack cocaine: an increase in use among patients attending clinics in São Paulo: 1990-1993. Subst Use Misuse 1996; 31:519-27.

10. Carlini EA, Nappo AS, Galduróz JC. A cocaína no Brasil ao longo dos últimos anos. Rev ABP-APAL 1993; 15:121-7.

11. Uchôa MA. Crack: o caminho das pedras. São Paulo: Editora Ática; 1996.

12. Galduróz JC, Noto AR, Nappo SA, Carlini EA. I Levantamento domiciliar nacional sobre uso de drogas psicotrópicas - Parte A: estudo envolvendo as 24 maiores cidades do estado de São Paulo (1999). São Paulo: Fundação de Amparo à Pesquisa do Estado de São Paulo/Centro Brasileiro de Informações sobre Drogas Psicotrópicas; 2000.

13. Carlini EA, Galduróz JC, Noto AR, Nappo SA. I Levantamento domiciliar nacional sobre uso de drogas psicotrópicas no Brasil (2001). São Paulo: Secretaria Nacional Antidrogas/Centro Brasileiro de Informações sobre Drogas Psicotrópicas; 2002.

14. Carlini EA, Carlini-Cotrim B, Silva-Filho AR, Barbosa MTS. Consumo de drogas psicotrópicas no Brasil, em 1987. Brasília: Ministério da Saúde/ Ministério da Justiça; 1989. (Série C: Estudos e Projetos 5).

15. Carlini EA, Carlini-Cotrim B, Silva-Filho AR, Barbosa MTS. II Levantamento nacional sobre o uso de psicotrópicos em estudantes de primeiro e segundo graus - 1989. São Paulo: Centro Brasileiro de Informações sobre Drogas Psicotrópicas; 1990.

16. Galduróz JCF, D’Almeida V, Carvalho V, Carlini EA. III Levantamento sobre o uso de drogas entre estudantes de 1 o e 2 o graus em 10 capitais brasileiras - 1993. São Paulo: Centro Brasileiro de Informações sobre Drogas Psicotrópicas; 1994.
17. Galduróz JC, Noto AR, Carlini EA. IV Levantamento sobre uso de drogas entre estudantes de 1o e 2 o graus em 10 capitais brasileiras (1997). São Paulo: Associação Brasileira da Indústria Farmacêutica/ Associação Brasileira de Farmacêuticos/Conselho Federal de Enfermagem/Centro Brasileiro de Informações sobre Drogas Psicotrópicas; 1997.

18. Galduróz JC, Noto AR, Fonseca AM, Carlini EA. V Levantamento nacional sobre o consumo de drogas psicotrópicas entre estudantes do ensino fundamental e médio da rede pública de ensino nas 27 capitais brasileiras - 2004. São Paulo: Secretaria Nacional Antidrogas/Centro Brasileiro de Informações sobre Drogas Psicotrópicas; 2005.

19. Abramovay M, Castro MG. Drogas nas escolas versão resumida. Brasília: Organização das Nações Unidas para a Educação, a Ciência e a Cultura; 2005.

20. Magalhäes MP, Barros RS, Silva MTA. Uso de drogas entre universitários: a experiência com maconha como fator delimitante. Rev ABP-APAL 1991; 13:97-104.

21. Queiroz S. Fatores relacionados ao uso de drogas e condições de risco entre alunos de graduação da USP [Doctoral Dissertation]. São Paulo: Faculdade de Saúde Pública, Universidade de São Paulo; 2000.

22. Barria ACR, Queiroz S, Nicastri S, Andrade AG. Comportamento do universitário da área de biológicas da Universidade de São Paulo, em relação ao uso de drogas. Rev Psiquiatr Clín (São Paulo) 2001; 27:215-24.

23. Plotnik R, Azmus AD, Tannhauser M, Tannhauser SL. Utilização de psicotrópicos por estudantes universitários. Pesqui Méd (Porto Alegre) 1986; 20:109-13.

24. Brenes LFV, Hammes MF, Solé MTV, Hein R, Ramil KAA. Drogas ilícitas entre universitários. Rev AMRIGS 1986; 30:140-3.

25. Albino M, Borges V, Büchele F. Perfil epidemiológico sobre drogas lícitas e ilícitas dos estudantes universitários do Campus Unidade Pedra Branca - UNISUL. Rev Bras Psiquiatr 2002; 24 Suppl 2: 5-25.

26. Noto AR, Galduróz JC, Nappo AS, Fonseca AM, Carlini CMA, Moura YG, et al. Levantamento nacional sobre uso de drogas entre crianças e adolescentes em situação de rua nas 27 capitais brasileiras - 2003. São Paulo: Secretaria Nacional Antidrogas/Centro Brasileiro de Informações sobre Drogas Psicotrópicas; 2003.

27. Campos R, Raffaelli M, Ude W, Greco M, Ruff A, Rolf J, et al. Social networks and daily activities of street youth in Belo Horizonte, Brazil. Child Dev 1994; 65:319-30.

28. Figueroa ARM. Uso de drogas por meninos de rua, uma abordagem psicossocial [Tese de Doutorado]. Rio de Janeiro: Universidade Federal do Rio de Janeiro; 1990.

29. Malbergier A. Transtornos psiquiátricos em usuários de drogas injetáveis infectados pelo HIV. J Bras Psiquiatr 1998; 48:253-62. 
30. Nappo AS, Sanchez ZM, Oliveira LG, Santos AS, Coradete Júnior J, Pacca JCB, et al. Comportamento de risco de mulheres usuárias de crack em relação às DST/AIDS. São Paulo: Centro Brasileiro de Informações sobre Drogas Psicotrópicas; 2004.

31. Brasiliano S, Hochgraf PB, Torres RS. Comportamento sexual de mulheres dependentes químicas. Rev Bras Psiquiatr 2002; 24 Suppl 2:5-25.

32. Bassols AMS. Adolescência e infecção pelo HIV: situação de risco e proteção, auto-estima e sintomatologia psiquiátrica [Doctoral Dissertation]. Porto Alegre: Universidade Federal do Rio Grande do Sul; 2003.

33. Pechansky FI, von Diemen LI, Kessler FI, Hirakata VI, Metzger DII, Woody G. Incidência de infecção por HIV entre abusadores de cocaína em Porto Alegre. Rev Bras Psiquiatr 2002; 24 Suppl 2:5-25.

34. Silva AMC. Fatores de risco para doenças sexualmente transmissível em Cuiabá, Mato Grosso [Doctoral Dissertation]. Cuiabá: Universidade Federal do Mato Grosso; 1999.

35. Souza CTV. Características sociodemográficas, comportamentais e vulnerabilidade à infecção pelo vírus da imunodeficiência humana em homens que fazem sexo com homens do Projeto Rio [Doctoral Dissertation]. Rio de Janeiro: Fundação Oswaldo Cruz; 2001

36. Azevedo RCS. Usuários de cocaína e AIDS: um estudo sobre comportamento de risco [Doctoral Dissertation]. Campinas: Universidade Estadual de Campinas; 2000.

37. Silva SL. Mulheres da luz: uma etnografia dos usos e preservação no uso do crack [Doctoral Disseration]. São Paulo: Faculdade de Saúde Pública, Universidade de São Paulo; 2000.

38. Silva NG. Fatores associados à infecção por HIV entre trabalhadoras do sexo na cidade de Santos [Masters Thesis]. São Paulo: Universidade de São Paulo; 2004.

39. Weiser SD, Dilworth SE, Neilands TB, Cohen J, Bangsberg DR, Riley ED. Gender-specific correlates of sex trade among homeless and marginally housed individuals in San Francisco. J Urban Health 2006; 83:736-40.

40. Passos ADC, Figueiredo JFC. Fatores de risco para doenças sexualmente transmissíveis entre prostitutas e travestis de Ribeirão Preto (SP), Brasil. Rev Panam Salud Pública 2004; 16:95-101.

41. Santos NJS. As mulheres e a AIDS [Docotral Dissertation]. São Paulo: Faculdade de Saúde Pública, Universidade de São Paulo; 1994.

42. Turchi MD. Perfil de risco e estimativa de ocorrência de infecções de transmissão sangüínea ou sexual - HIV, hepatite B, hepatite C, HTLV I/II e sífilis - entre usuários de cocaína, em São Paulo [Doctoral Dissertation]. São Paulo: Universidade Federal de São Paulo; 2000.

43. Dunn J, Laranjeira RR. HIV-risk behaviour among non-heroin using cocaine injectors and noninjectors in São Paulo, Brazil. AIDS Care 2000; 12:471-81.

44. Ferri CP. Cocaína: padrão de consumo e fatores associados à procura de tratamento [Doctoral Dissertation]. São Paulo: Universidade Federal de São Paulo; 1999.
45. Ribeiro M. Seguimento de cinco anos com usuários de crack: evolução dos padrões de consumo, sociodemográficos e de mortalidade [Doctoral Dissertation]. São Paulo: Universidade Federal de São Paulo; 2005.

46. Barcelos NT. Prevalência e fatores de risco para infecção pelo HIV em uma população de indivíduos testados em centros de aconselhamento no sul do Brasil [Doctoral Dissertation]. Porto Alegre: Universidade Federal do Rio Grande do Sul; 2000.

47. Carvalho HB, Bueno R. Infecção pelo HIV e seus determinantes em sete cidades brasileiras - Projeto Brasil. In: Mesquita F, Seibel S, organizadores. Consumo de drogas - desafios e perspectivas. São Paulo: Editora Hucitec; 2000. p. 21-54.

48. Mesquita F, Kral A, Reingold A, Bueno R, Trigueiros D, Araújo PJ, et al. Trends of HIV infection among injection drug users in Brazil in the 1990s: the impact of changes in patterns of drug use. J Acquir Immune Defic Syndr 2001; 28:298-302.

49. Carvalho ACC. Prevalência de infecção e doença tuberculosa entre usuários de drogas injetáveis da cidade do Rio de Janeiro [Doctoral Dissertation]. Rio de Janeiro: Universidade Federal do Rio de Janeiro; 1996.

50. Ferreira Filho OF. Estimativa da prevalência de tuberculose infecção e doença entre usuários de cocaína, internados em alguns serviços hospitalares da Grande São Paulo [Doctoral Dissertation]. São Paulo: Universidade Federal de São Paulo; 1999.

51. Galperim B. Prevalência da infecção pelo vírus da hepatite $\mathrm{C}$ em pacientes internados em unidade de dependência química [Masters Thesis]. Porto Alegre: Fundação Faculdade Federal de Ciências Médicas de Porto Alegre; 2000

52. Motta TQR. Co-infecção HIV/VHC: estudo da prevalência e da evolução clínica e mortalidade em pacientes co-infectados atendidos em Vitória-ES [Masters Thesis]. Vitória: Universidade Federal do Espírito Santo; 2003.

53. Nappo SA, Galduróz JC, Raymundo M, Carlini EA. Changes in cocaine use as viewed by key informants: a qualitative study carried out in 1994 and 1999 in Sao Paulo, Brazil. J Psychoactive Drugs 2001; 33:241-53.

54. Guindalini C, Vallada H, Breen B, Laranjeira R. Concurrent crack and powder cocaine users from Sao Paulo: do they represent a different group? BMC Public Health 2006; 6:10.

55. Sanchez ZM, Nappo SA. Seqüência de drogas consumidas por usuários de crack e fatores interferentes. Rev Saúde Pública 2002; 36:420-30.

56. Dunn J, Laranjeira R. Cocaine: profiles, drug histories, and patterns of use of patients from Brazil. Subst Use Misuse 1999; 34:1527-48.

57. Bastos FI, Lopes CS, Dias PRTP, Lima ES, Oliveira SB, Luz TP. Perfil de usuários de drogas. I. Estudo de características de pacientes do NEPAD/UERJ - 1986/1987. Rev ABP-APAL 1988; 10:47-52.

58. Silveira Filho D, César AC. Perfil de usuários de drogas: caracterização dos pacientes atendidos no ambulatório do PROAD/EPM em 1989. Rev ABP-APAL 1991; 13:39-42. 
59. Castel S, Malbegier A. Farmacodependências: estudo comparativo de uma população atendida em serviço especializado: 1984-1988. Rev ABP-APAL 1989; 11:126-32.

60. Scivoletto S. Tratamento psiquiátrico ambulatorial de adolescentes usuários de drogas: características sócio-demográficas, a progressão do consumo de substâncias psicoativas e fatores preditivos de aderência e evolução no tratamento [Doctoral Dissertation]. São Paulo: Universidade de São Paulo; 1997.

61. Passos SR, Camacho LAB. Características da clientela de um centro de tratamento para dependência de drogas. Rev Saúde Pública 1998; 32:64-71.

62. Scivoletto S, Henriques Júnior SG, Andrade AG. Uso de drogas por adolescentes que buscam atendimento ambulatorial: comparação entre "crack" e outras drogas ilícitas. Um estudo piloto. Rev ABPAPAL 1997; 19:7-17.

63. Fochi EL, Moraes MS, Chiaravalloti Neto F, Gandolfi D, Ferreira EMA. Caracterização de 46 usuários de crack abordados pelo Programa de Redução de Danos “Tá Limpo”. HB Cient 2000; 7:85-91.

64. Zilberman ML, Hochgraf PB, Brasiliano S, Milharcic SI. Drug-dependent women: demographic and clinical characteristics in a Brazilian sample. Subst Use Misuse 2001; 36:1111-27.

65. Ferreira Filho OF, Turchi MD, Laranjeira R, Castelo A. Perfil sociodemográfico e de padrões de uso entre dependentes de cocaína hospitalizados. Rev Saúde Pública 2003; 37:751-9.

66. Borini P, Guimarães RC, Borini SB. Usuários de drogas ilícitas internados em hospital psiquiátrico: padrões de uso e aspectos demográficos e epidemiológicos. J Bras Psiquiatr 2003; 52:171-9.

67. Silveira RA. Caracterização dos adolescentes internados por álcool e outras drogas na cidade de Curitiba [Doctoral Dissertation]. Curitiba: Universidade Federal do Paraná; 2001.

68. Magrinelli M, Kessler F, Pechansky F, Araújo R, Oliveira MS, Souza AC. Características do uso de cocaína em indivíduos internados em unidades de tratamento de Porto Alegre, RS. J Bras Psiquiatr 2004; 53:351-8.

69. Dunn J, Ferri CP, Laranjeira R. Does multisite sampling improve patient heterogeneity in drug misuse research? Drug Alcohol Depend 2001; 63:79-85.

70. Dunn J, Laranjeira R. Transitions in the route of cocaine administration - characteristics, direction and associated variables. Addiction 1999; 94: 813-24.

71. Leite MC. Relações entre dependência de cocaína e transtorno depressivo: contribuição para o estudo da co-morbidade psiquiátrica em pacientes dependentes de substâncias psicoativas [Masters Thesis]. São Paulo: Universidade de São Paulo; 1996.

72. Cruz MS. Abstinência de cocaína: um estudo de características psicopatológicas em dependentes que procuram tratamento [Masters Thesis]. Rio de Janeiro: Instituto de Psiquiatria, Universidade Federal de Rio de Janeiro; 1996.

73. Terra MB. Fobia social e transtorno de pânico em pacientes dependentes de substâncias psicoativas hospitalizados [Masters Thesis]. Rio de Janeiro: Universidade Federal do Rio de Janeiro; 2000.
74. Magrinelli M. Padrões de consumo e motivação para a mudança em dependentes de cocaína [Doctoral Dissertation]. Porto Alegre: Pontifícia Universidade Católica do Rio Grande do Sul; 2003.

75. Lopes CS, Coutinho ES. Transtornos mentais como fatores de risco para o desenvolvimento de abuso/dependência de cocaína: estudo caso-controle. Rev Saúde Pública 1999; 33:477-86.

76. Moura MES. Comorbidade entre dependência de pasta-base e indicadores de transtorno depressivo de humor com o emprego do Self Rating Questionnaire (SRQ-20) [Doctoral Dissertation]. Rio de Janeiro: Universidade Federal do Rio de Janeiro; 2001.

77. Ferri CP, Dunn J, Gossop M, Laranjeira R. Factors associated with adverse reactions to cocaine among a sample of long-term, high-dose users in São Paulo, Brazil. Addict Behav 2004; 29:365-74.

78. Mesquita F, Kral A, Reingold A, Haddad I, Sanches M, Turienzo G, et al. Overdoses among cocaine users in Brazil. Addiction 2001; 96:1809-13.

79. Passos SRL. Fatores associados ao abandono de tratamento ambulatorial para dependência de drogas entre pacientes de um centro de referência no Rio de Janeiro [Doctoral Dissertation]. Rio de Janeiro: Escola Nacional de Saúde Pública, Fundação Oswaldo Cruz; 1996.

80. Castel S. Fatores de predição de prognóstico de farmacodependentes avaliados pela escala de seguimento de dependentes de substâncias psicoativas [Doctoral Dissertation]. São Paulo: Universidade de São Paulo; 1997.

81. Zilberman ML, Tavares H, Andrade AG, El-Guebaly $\mathrm{N}$. The impact of an outpatient program for women with substance-related disorders on retention. Subst Use Misuse 2003; 38:2109-24.

82. Leite MC. Fatores preditivos de resposta terapêutica em tratamento ambulatorial para dependentes de cocaína [Doctoral Dissertation]. São Paulo: Universidade de São Paulo; 1999.

83. Wagner AV. A comorbidade entre dependência à cocaína e depressão, como fator associado à desistência ao tratamento em comunidade terapêutica [Masters Thesis]. Pelotas: Universidade Católica de Pelotas; 2002.

84. Ribeiro M, Dunn J, Laranjeira R, Sesso R. High mortality among young crack cocaine users in Brazil: a 5-year follow-up study. Addiction 2004; 99:1133-5.

85. Almeida AMT. II levantamento epidemiológico do uso de drogas entre estudantes de 1o e 2 o graus da rede estadual de ensino de Cuiabá-MT, 1997 [Doctoral Dissertation]. Cuiabá: Universidade Federal do Mato Grosso; 1999.

86. Campbell J, Gabrielli W, Laster LJ, Likow BI. Eficácia do tratamento em ambulatório do abuso de substâncias. J Addict Dis 1998; 2:43-54.

87. Ferri CP, Gossop M, Rabe-Hesketh S, Laranjeira R. Differences in factors associated with first treatment entry and treatment re-entry among cocaine users. Addiction 2002; 97:825-32.

88. Boskovitz EP. Levantamento do uso de drogas psicotrópicas entre estudantes de 1o e 2o graus da rede estadual de ensino de São José do Rio PretoSP [Doctoral Dissertation]. São José do Rio Preto: Faculdade de Medicina de São José do Rio Preto; 1999. 
89. Muza GM, Bettiol H, Muccillo G, Barbieri MA. Consumo de substâncias psicoativas por adolescentes escolares de Ribeirão Preto, SP (Brasil). I - Prevalência do consumo por sexo, idade e tipo de substância. Rev Saúde Pública 1997; 31:21-9.

90. Guimarães JL, Godinho PH, Cruz R, Kappann JI, Tosta Jr. LA. Consumo de drogas psicoativas por adolescentes escolares de Assis, SP. Rev Saúde Pública 2004; 38:130-2.

91. Vieira DL. Álcool: acesso, uso e conseqüências - um levantamento com estudantes do ensino fundamental e médio da cidade de Paulínia (SP) [Doctoral Dissertation]. São Paulo: Universidade Federal de São Paulo; 2006.

92. Soldera M, Dalgalarrondo P, Corrêa-Filho HR, Silva CAM. Uso de drogas psicotrópicas por estudantes: prevalência e fatores sociais associados. Rev Saúde Pública 2004; 38:277-83.

93. Godoi AMM, Muza GM, Costa MP, Gama MLT. Consumo de substâncias psicoativas entre estudantes de rede privada. Rev Saúde Pública 1991; 25:150-6.

94. Souza DPO, Martins DTO. O perfil epidemiológico do uso de drogas entre estudantes de 1o e 2 o graus da rede estadual de ensino de Cuiabá, Brasil, 1995. Cad Saúde Pública 1998; 14:391-400.

95. Baus J, Kupek E, Pires M. Prevalência e fatores de risco relacionados ao uso de drogas entre escolares. Rev Saúde Pública 2002; 36:40-6.

96. Tavares BF, Béria JU, Lima MS. Prevalência do uso de drogas e desempenho escolar entre adolescentes. Rev Saúde Pública 2001; 35:150-8.

97. Deitos FT, Santos RP, Pasqualotto AC, Segat FM, Guilande S, Benvegnú LA. Prevalência do consumo de tabaco, álcool e drogas ilícitas em estudantes de uma cidade de médio porte no sul do Brasil. Inf Psiquiatr 1998; 17:11-6.

98. Andrade AG, Bassit AZ, Mesquita AM, Fukushima JT, Gonçalves EL. Prevalência do uso de drogas entre alunos da Faculdade de Medicina da Universidade de São Paulo (1991-93). Rev ABP-APAL 1995; 17:41-6.
99. Andrade AG, Bassit AZ, Kerr-Corrêa F, Tonhon AA, Boscovitz EP, Cabral M, et al. Fatores de risco associados ao uso de álcool e drogas na vida, entre estudantes de medicina do Estado de São Paulo. Rev ABP-APAL 1997;19:117-26.

100. Fabris MB. Características sócio-econômicas, psicológicas, padrões de consumo de substâncias psicoativas e percepção de risco para doenças sexualmente transmissíveis em estudantes recémadmitidos numa universidade privada no interior paulista [Doctoral Dissertation]. Botucatu: Universidade Estadual Paulista; 2002.

101. Ribeiro MS, Ronzani FAT, Alves MJM. Consumo de substâncias psicoativas entre estudantes de medicina da UFJF. J Bras Psiquiatr 1997; 46:631-8.

102. Pereyra WJF, Brito AO, Oliveira CHC, Silva FAFR, Canela GGC, Gontijo GHS, et al. Avaliação do uso de drogas por estudantes de medicina. Rev Méd Minas Gerais 2000; 10:8-12.

103. Souza FGM, Landim RM, Perdigão FB, Morais RM, Carneiro-Filho BA. Consumo de drogas e desempenho acadêmico entre estudantes de medicina no Ceará. Rev Psiquiatr Clín (São Paulo) 1999; 26:188-94.

104. Torres R. Perfil epidemiológico do uso de drogas entre universitários da área da saúde [Doctoral Dissertation]. Fortaleza: Universidade Federal do Ceará; 2002.

105. Coelho MEA. O uso de drogas entre estudantes universitários da área da saúde: uma proposta de educação em saúde [Doctoral Dissertation]. Fortaleza: Universidade de Fortaleza; 2002.

106. Canuto MHA. Uso e abuso de drogas lícitas e ilícitas em jovens do 1o ano da Universidade Federal de Goiás [Doctoral Dissertation]. Belo Horizonte: Universidade Federal de Minas Gerais; 2003.

Submitted on 09/Oct/2006

Final version resubmitted on 26/Sep/2007

Approved on 30/Oct/2007 